This report was prepared as an account of work sponsored by an agency of the United States Government. Neither the United States Government nor any agency thereof, nor any of their emplayees, makes any warranty, express or implied, or assumes any legal liability or responsibility for the accuracy, completeness, or usefulness of any information, apparatus, product, or process disclosed, or represents that its use would not iniringe privately owned rights. Reference herein to any specific commercial product. process, or service by trade name, trademark, manufacturer, or otherwise docs not necessarily constitute or imply its endorsenient, recommendation, or favoring by the United States Government or any agency thereol. The views and opinions of authors expressed herein do not necessarily state or rellect those of the United States Government or any agency thereof.

\title{
Semiconductor Research Capabilities at the Lawrence Berkeley Laboratory
}

Office for Planning and Derelopnicnt

Lawrence Berkeley Laboratory

University of California

Berkeley. California 94720

February 1987

This work was supported by the U.S. Department of Energy under Contract No. DE-AC03-76SF00098. 


\section{LEGAL, NOTICE}

This book was prepared as an account of work sponsored by an agency of the l'nited States Guvernment. Neither the Lnited States Guvemment nor any agency thercof, nor any of their employees, inakes any warranty, express or inplied, or assurnes any legal liability or responsibitity for the accuracy, completeness, or usefulness of any information, apparatus, product, or process disclosed, or represents that its use would not infringe privately ouned rights. Relerence herein to any specific commercial product. process, or service by trade name, tradematk, manufacturer. or otherwise, does not necessarily constitute or imply its endorsement, recommendation. or favor. ing by the L'nited States Government or any agency thereof. The views and opinions of authors expressed herem do not necessarily state or reflect those of the I'nited States Covernment or any agency thereof. 


\section{Table of Contents}

Page

Introduction ......................................................................................................... I

Stmiconductor Research Capabilities ............................................................ I

National User Facilities .......................................................................... 2

Advanced Material ....................................................................................................... 2

Theoretical Predictive Capabilities ................................................................ ?

Crystal Growth ............................................................................ 2

Characterization Capabilities ……………….......................................... 3

Semiconductor Processing Science ............................................................................ 4

Lithography ........................................................................................... 4

Ion Implantation .......................................................................................... 4

Plasma Etching .............................................................................................. 5

Semiconductor-Metal Interfaces and Reactions ............................................. 5

Paciaging Science ...................................................................................................... 5

Fatiguc Resistant Solders ............................................................................... 5

Interfacial Adhesion of Ceramics and Metals ................................................. 5

Properties of Polymer IC Packaging Materials ............................................. 6

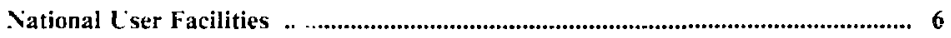

National Center for Electron Microscopy ..................................................... 6

Heavy-Ion Accelerators for Radiation Hardening Studies ................................ 7

Advanced Lighı Source ...................................................................................... 7 


\section{Introduction}

Lawrence Berkeley Laboratory (LBL) is a multiprogrant natwonal laboratory managed by the Liniversicy of (alilurnia for the l'.S. Department of Energ! (DOE). The Laborators is adjacent to the I'niversity of (alifornia. Berkeley. and has more than 3000 emplosees. Its operating budget of about $\$ 155$ million supports a wide range of research aclisiles. (urrent programs encompass all the natural selences. as well ats enginerering. mathematuss and compuler science.

Besides its restareh role. he Laboratory series the ration and its scientilic and educationa! communities by descloping and operating national experimental faculities for use by qualified investigators. Training future generations of scientists and enguects in another Laboratory role. as is the fostering of produclive relationships between LBL rescarch programs and industr?.

\section{Semiconductor Research Capabilities}

Much of the Laboratory"s expertise in semiconductor devices has grown oul oflong-standing sfforts in the development of radiation detectors for rescarch in nutlear and particle physics. Detector systems for high-energ! physics research continue to grow in size and complexity, and highly integraled front-end circuitry with data presclection is an essential part of current detector designs. LBL has an active program in integrated circuit (IC) design and advanced silicon device research and deselopment for the U.S. highenergy physics program (Figure 1).

Semiconductor detector research led to the development of growth techniques for ultrapure germanium. This material is used both in large volume radiation deteetors and in bolometers for infraied astronomy. Subseguently. the germaniun research evolved into the current program in GaAs (gallium arsenide) crystal growth and characterization in the Laboratory"s Center for Adranced Matcrials (CAM). which was formed in October 1983. to provide a structure for more explicily focusing some of the Laboratory's talents and resources on basic matcrials research in support of the future needs of U.S. industry.

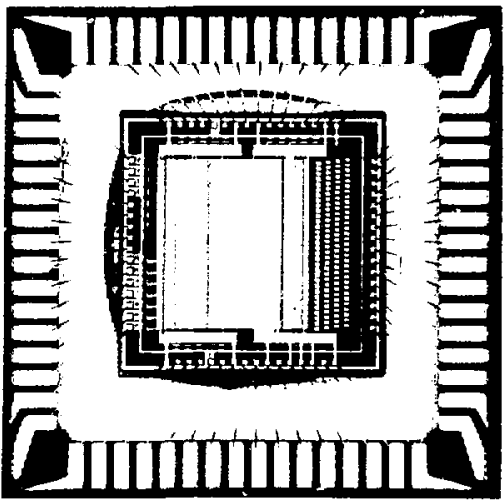

Figure 1. In integrated readout system for high-energy ohystes detectors. This IC uncludes 138 chennels of low-noistpreamplifiers with assocosted "hat" resogntaon curcuitry and

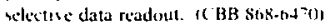

Interactions with industrial scientists are a key facel of the overall $\mathrm{C} A \mathrm{M}$ concept.

Another Laboratory (enter. the Center for $\mathrm{X}$ Ray Optics, scrves as a focal point for activities aimed at exploiting a broad slice of the electromagnetic spectrum, nancly, the soft $x$-ray and vacuum-ultraviolet regions. LBL scientists have collaborated in the development of an $x$-ray microscope at the National Synchrotron Light Source, using a zone plate produced jointly with IBM (Figure 2). This development has the capability to probe nuaterial surfaces and thin films at resolutions far finer than current (or projected) $1 \mathrm{C}^{\circ}$ feature sizes.

Other basic and applied research programs at LBL continuc to make important contributions to semiconductor materials science. for example. development of powerful models for predicting superconductivily, electronic properties. and crystal structure of materials based only on atomic propertics: the mechanism of formation of structural defects associated with ion implantation in 


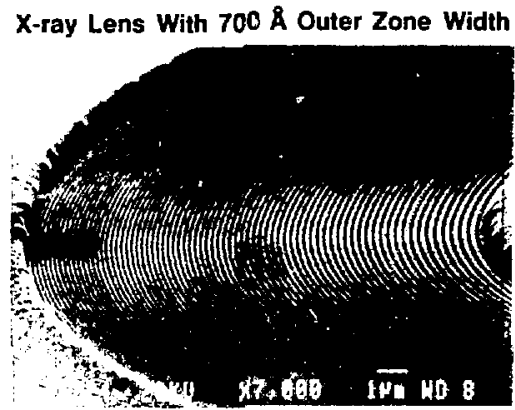

Figure 2. Porluon of a zone plate that can be used for focus. ing soft v-rass. These structures are made as part of a colla. horalase rewearch program be/ween the Nanolithography Group of IHSI's 11 atson Rescarch (enter and LBL' Cimer for X-Ray Optics, (XBB 860-8114)

Si and (ja)ts: amorphous laytr formation and kinctics of solid-state regrowth of erystalline material: heterojunction solar cell development: the clucidation of properties of the interfaces between metals and compound sumiconductors: and radiation damage effects.

\section{National L'ser Facilities}

Several of the Laborators is national user facilitics are ideally suited lor the study and characterization of semiconductors and related clectronic materials. including its heas-ion accelerators and high-resolution electron microscopes. Laboratory capabilities also include a wide range of structurai and electrical characterization lacilities and cxpertisc.

The following sections identify examples of rescarch capabilitiss in advanced materials. semiconductor processing. and packaging techniques. Imporiant large-scale scicnific facilities and other instrumentation and expertise at LBL are also identified: key contacts for further intormation regarding these resources are provided. For further overview intormation on industry-related seniconductor research at LBL. contaci Gerd M. Rosenblatt. Deputy Director. at $(+15) 486-6606$.

\section{Advanced Materials}

\section{Theoretical Predictive Capabilities}

Solid-state theorists at LBL have developed microscopic theory based on quantum mechanics to explain and predict propertics of semiconductor materials, surfaces. and interfaces. Electronic. optical, and structural properties of solids. including new materials not previously ș'nthesized. have been predicted and subseaucntly confirmed. The motivation for the rescarch is modeling the properties of real materials and predicting the existence of new materials.

Recendy. this theory has been used to investigate the possibility of supcrconductivity in silicon at high pressure. Predietions of the relative stabilities of high-pressurc metallic phases of silicon and the occurrence of superconductivity in the simple-hexagonal siructure havi been experimentaliy confirmed.

\author{
Contact: Marvin L. Cohen \\ Matcrials and Chemical Scienses \\ Division \\ (4I5) $642-4753$
}

\section{Crystal Growth}

The Laboratory has two special-purpose semiconductor crystal growth facilitics. The Gats laboratory (Figure 3) is equipped with two computer-controlled three-zone multiheating element gradient freeze furnaces with 3 -inch and 5 incl diameters. respectively. Single crystals weighing up $102 \mathrm{~kg}$ are routinely grown. Three scientists and a technician work on Ga-ts erystal growth. The germanium laboratory. staffed b; two scientists and a technician. is equipped with two zone refining machines and wo Czochralskiype furnaces. Single crystals up to $1.5 \mathrm{~kg}$ in 


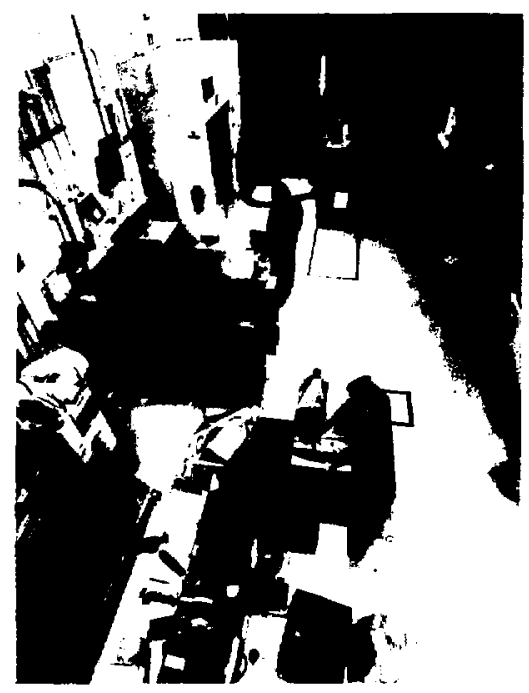

Figure 3. Gallium arsenide laboratory with crystal growth chimbers (bartaround and cenier). fume hoods (rigbi). waler slicing equipmstit (lower le[1). and analỵıcal benches. Satellite analyicicl laboratories provide for a wide range of spectroscopy capabiluties from $x$-ras to the far infrared, as well as etching and paramagnetic resonance facilities. (CBB 8610-9756)

weight can be grown routincly with electrically active impurity concentrations of $\leqslant 10^{10} \mathrm{~cm}^{-3}$. Spccial ultrapure or dopcd crystals for research and for infrared photoconductors are also grown.

Contact: Eugene E. Haller Center for Advanced Materials (4l 5) 486-5294

\section{Characterization Capabilities}

A number of characterization techniques are available at LBL for the comprehensive evaluation of as-grown and processed semiconductors. The techniques for structural characterization include:

- Rutherford backscattering (RBS):

- Particle-induced x-ray emission (PIXE);

- Nuclear activation analysis;

- Atomic-resolution scanning transmission clectron microscopy (STEM):

- Prefercntial photoetching:

- X-ray techniques-.. topography, diffraction, photoclectric spec1roscopy, fuorescence and absorption fine structure spectroscopy (EXAFS).

Many techniques are also utilized at LBL for semiconductor electronic characterization. These techniques and instrumentation include:

- Semiautomatic system for variable tempcrature $(2-400 \mathrm{~K})$ mcasurements of the Hall effect and resistivity;

- Deep level transient spectroscopy (with uniaxial stress option) for defect identification;

- Optical system for subband-gap absorption measurements:

- Fourier far-infrared spectrometers:

- Phọtothermal ionization spectroscopy (PTIS) for ultrapure crystals;

- Electron paramagnetic resonance (EPR) and photo-EPR:

- Raman scattering spectroscopy:

- Positron lifetime measurements.

Contact: Eugene E. Haller

Center for Advanced Materials (4is 486-5294) 


\section{Semiconductor Processing Science}

\section{Lithography}

Synchrolron radiation offers the polential for high-resolution x-ray lithography:. LBL scientists have developed the world's brightest $x$-ray' source with the LBL-Exxon wiggler installed at the Stanford Synclirotron Radialion Laboralory (SSRL) (Figure 4). At LBL. the Advanced Light Source (ALS), scheduled for completion in 1992. will have outslanding capabilitics for research related to advanced materials and lithography. To highlight one possibility. the developnent of advanced imaging lectiniques (by means of projection optics) rather than proximity printing may be the key to lithography for $256-\mathrm{Mbit}$ DRAM chips and beyond. The ALS will provide beams with the high-power, smalt-beam size. and low-angular divergence needed for research in high-resolution. high-llıroughput $\mathrm{x}$-ra! lithography:

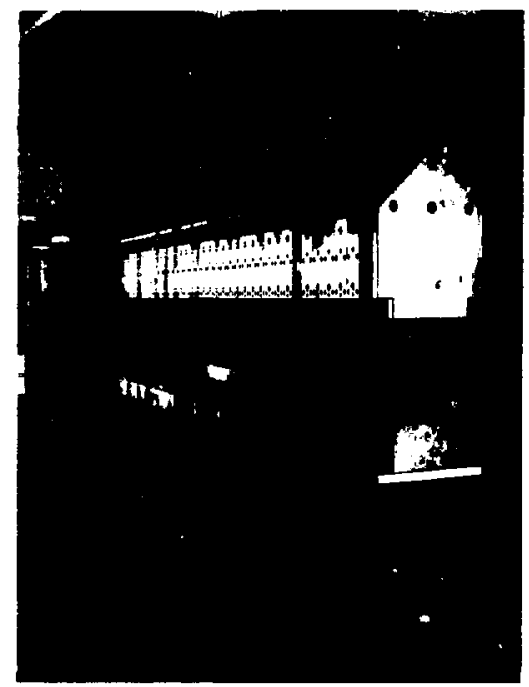

Figure 4. The LBL_Exxon wiggler magnet now installed at the Stanford Synchroiron Radiation Laboratory is the world's brightest source of $x$-ray beams. Beams at this and other facililies can be used for a wide range of semiconductor materials sludies and for the development of advaneed lithography techniques. (CBB 833-1798)
The LBL accelerator physies code "ZAP" for optimizing synchrolron and storage ring parameters has been used in the development of several commercial designs for compact "industrial" synchrotron radiation sources.

Contact: David T. Attwood Center for X-Ray Oplics (415) $486-4463$

\section{Ion Implantation}

LBL has expertise. test stands. and fabrication facilities for ion source development. An cxample is LBL's Metal Vapor Vacuum Are (MEVVA) ion source (Figure 5). This and several other ion sources can deliver a range of ions at high current with excelsent reliability. They highlight the considerable expertise present in the area of souree development. These sources have not been applied to semiconductor ion implantation, but these and their developments have potential for the scmiconductor industry.

A lathanum hexaboride cathode developed at LBL produces cold electrons as required for the neutralization of insulators during positive-ion implantation. Although the design and development of these cathodes originated from a range of basic research needs. an important application is now linked to IC fabrication.

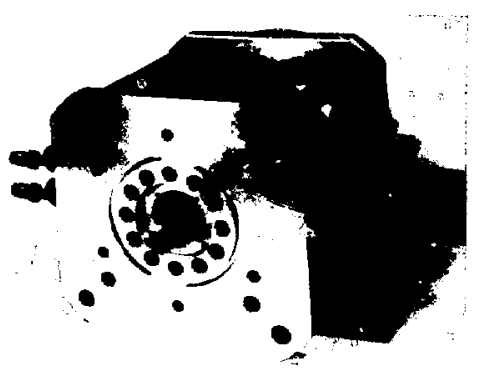

Figure 5. The Metal Vapor Vacuun - Ire (MEVV A) ion source can produce a wide range of ions at exrents up to 500 $\mathrm{mA}$. Behind the extractor stction in the forcground is the plasma arc section (nol visible) where intenst eurrent concentrations (in excess of $10^{16} \cdot 1 / \mathrm{cm}^{2}$ ) produce a plasmat that plumes away from the cathode. (C' $|3| 384+2812$ ) 
Contact: Ian G. Brown

Accelerator and Fusion

Rescarch Division

(415) $486-4174$

\section{Plasma Etching}

The plasma research group at LBL has specialized for 15 years in the development and diagnostics of plasma sources and ion beamss. Recently. attention has been directed toward applying this technolog: to improved plasma eichers for semiconductor processing. The group has proposed to develop processes for an advanced highthroughput dry etcher with low radiation damage. The proposal includes experiments comparing ion and reactive species production in low-pressure and microwave plasmas. combined with the development of computer-aided plasma chemistry modeling and diagnostic techniques. Close conneclions to LC Berkeley groups and semiconductor companics active in this field would greatiy facilitate a vigorous collaborative program in this area.

Contact: Wulf Kunkel

Accelerator and Fusion

Research Division

(415) $486-5011$

\section{Semiconductor-Metal Interfaces and Reactions}

Metal contacts to semiconductors play a crucial role in the fabrication and electrical charaeteristics of semiconductor devices. This applies especially: to GaAs MESFET 1echnolog:; and a comprehensive and syslematic investigation of the reactions of thin metal films with solid GaAs has been carricd out by rescarchers in CAM. Information on the reaction kinetics and systematics as well as the reacted phase distributions. structure, stoichiometry, morphology, and stability has been obtained for a number of possible contact structures including thin films of Ti. Zr. V. Nb. Cr. Mo. W, Co. Rh. Ir, Ni. Pd. and Pt on (100) GaAs. Correlations between the electrical properties and interface melallurgy for some of the metal/GaAs systems have also been established. A defecl model of Schottky barrier formation has been proposed. The model is based on a new class of defects that change their electrical properties depending on the Fermi level position in the band gap. It is shown that pinning of the Fernit energy by the defects explains many of the propertics of "as-deposiled" and annealed GaAs-metal contacts.

Contact: Eugene E. Haller

Center for Advanced Materials (415) 486-5294

\section{Packaging Science}

\section{Fatigue Resistant Solders}

An important failure mechanism in semicorductor devices is thermal fatigue of contacts from periodic heating and cooling, a problem that intensifies with chip circuit density and power dissipation. Research at the Center for Advanced Matcrials is focusing on two areas: contaet design to avoid thermal fatigue and the development of solder contaets tinat have greater resistance to fatigue. New techniques have been developed for high-resolution examination of solders and wetled solder interfaces. Test structures and machines have been designed that permit straining of the solder interfuce in pure shear and also impose cyclic shear loads on solder contaets. These studies are revealing solder/copper contact microstruc- ture, metallurgieal mechanisms of microstructure development, and mechanical behavior of solder/copper contacts. including their strength. stress relaxation, and fatigue behavior.

Contact: J.W. Morris Center for Advanced Materials (415) 642-3815

\section{Interfacial Adhesion of Ceramics and IIetals}

Studies of ceramic-metal bond fracture may lead to improvements in clectrical components and assemblies where interfacial fai!ure disrupts clectrical continuity. corrosion protection. or other functions. The fraciure of ceramic-metal bonds is 
being studied at LBL in terms of interfacial themistry, crack tip deformation. and crack interactions with interface morphology and reaction phases.

Parallel analyses treat decohesion of deposited and reaction-formed filns, respectively, having high tensile and compressive residual stresses. These investigations rely on fracture mechanics measurements. advanced microstructural and interfacial characterization techniques, and indentation mcthods that induce iilm delamination. Samples from industrial microfabrication laboratories have been analyzed in the coitse of thins work.

\section{Contact: Roland M. Cannon}

Center for Advanced Materials

(415) 642-9338

\section{Properties of Polymer IC Packaging Materials}

Expertise in polymer technology is being directed to rescarch on mieroelectronic industry packaging malcrials at LBL's Center for Adranced Materials. This work includes: (1) evaluation of thermoclastic stresses in IC packages: (2) determination of diclectric constants and losses of packaging materials: and (3) analysis and control of moisture ingression into packages.

Contac1: Morton M. Denn

Center for Advanced Materials

(415) 642-0176

\section{National User Facilities}

\section{National Center for Electron Microscopy}

The National Center for Electron Microscopy (NCEM) at LBL provides state-of-thc-art facilitics for clectron-optical characterization of materials and $\mathrm{IC}_{\mathrm{C}}$. The resident staff operale and design equipmen! and software accessible to the national user conmunity. Central to NCEM are two unique high-voltage microscopes, the $1.5-\mathrm{MeV}$ High-Voltage Elcctroli Microscope (HVEM), which is the most powerful electron microscope in the U.S., and the I-McV Atomic Resolution Microscope (ARM), which offers the best resolution in the world--better than 1.6 \& (Figure 6). These microscopes are supported by "feeder" microscopes (for screening. preliminary experiments. and complementary microanalysis). preparation facilities, and image analysis facilities. Applications to semiconductors have included studies of bulk semiconductor materials and semiconductor interfaces (Figure 7).

Contact: Ronald Gronsks

National Center for

Electron Microscopy

(415) 486-5006

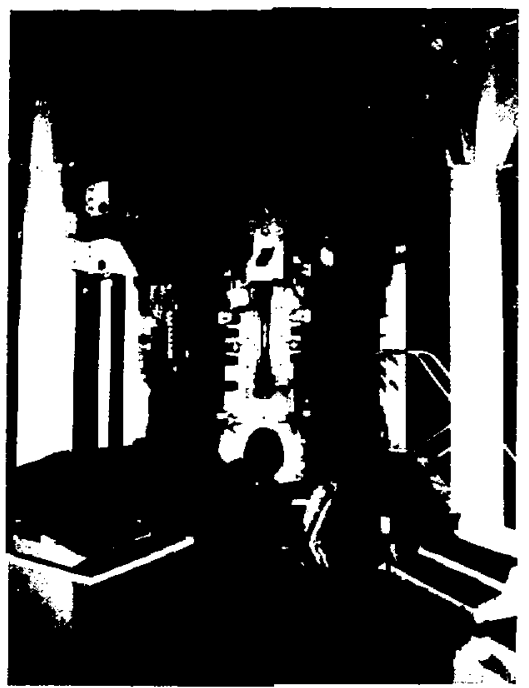

Figure 6. The Atomic Resolution Microscupe at the Siational Center for Electrun Slicroscopy. capable of better than 1.6-1 resolution. Tbe microscope is avaitable to industral users and has been used for a wide range of semicondurtor studies. (CBB 839.846\%) 

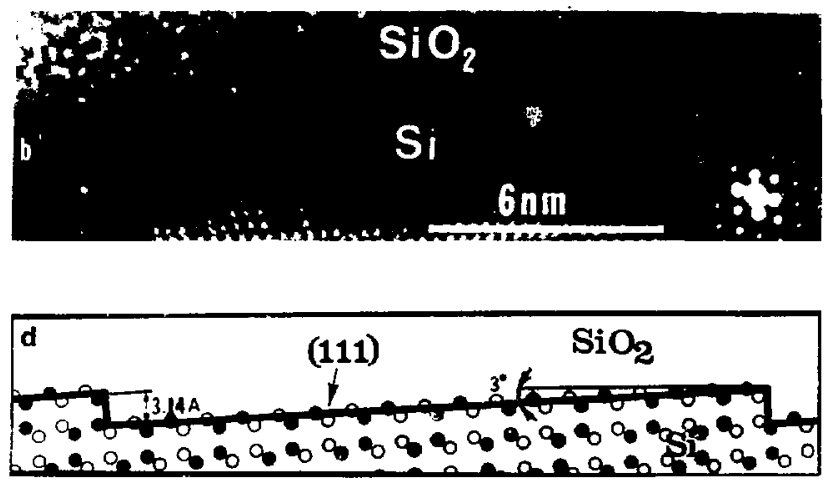

Figure 7. (a) Electron microscope image of the $\mathrm{Si-SiO}$ interface. The silicon surface orientation is $3^{\circ}$ off the (111) plant. The oxide was thermally grown to $1000 \mathrm{~A}$ thick. (b) Oplical diflractogram of tlac same image, (c)! $10 \overline{\mathrm{I}}$ diffraction patlern from the specimen imaged in (a). (d) Model of the slspped Si.SiO, interface. (XBB 832-1793C \& B)

\section{Heavy-Ion Accelerators for Radiation Hardening Studies}

Accelerators at LBL have been used in failure analysis and radiation hardening studies by many U.S. electronics companies. The Bevalac, which is capable of accelerating light iuns to $2.1 \mathrm{GcV}$; nucleon and heavier ions through uranium to energies as great as $960 \mathrm{MeV} /$ nucleon. has been used to test integrated circuits intended for spacebased applications, in order to test their resistance to cosmic rays. for example. In addition, during the past year, ions from the SuperHILAC were used for dcep ion implantation. The 88-Inch Cyclotron was used by more than two dozen companies during the last three years to test the sensitivity of high-speed ICs to radiation-indueed effects, such as single-erent upset. that would be encountered in a satellite environment in space.
Contact: Jose Alonso

Accelerator and Fusion

Research Division

(415) 486-5575 (SuperHILAC and Bevalac)

or Rober1 G. Stokstad Nuclear Science Division (415) 486-4088 (88-Inch Cyclotron)

\section{Advanced Light Source}

Enormous polential exists for using synchrotron radiation from bending magnets and insertion devices at electron storage rings. As described is the section on processing science, the Laboratory"s next-generation light source. scheduled for completion in 199:, will be an outstanding instrument for research related to advanced materials and lithography:

Contact: David T. Altwood Center for X-Ray Optics (415) $486-4463$ 
This report was done with support from the Depariment of Energy. Any conclusions or opinions expressed in this report represent solely those of the author(s) and not necessarily those of The Regents of the University of California, the Lawrence Berkeley Laboratory or the Department of Energy.

Rererence to a company or product ame does not imply approval or recommendation of the product by the University of Califomia or the U.S. Department of Energy to the exclusion of others that may be suitable. 